\title{
Editorial
}

\section{Welcome to Seminars in Thrombosis \& Hemostasis 2015: New (2013) Impact Factor and Most Highly Cited Articles}

\author{
Emmanuel J. Favaloro, PhD, FFSc (RCPA) ${ }^{1}$ \\ ${ }^{1}$ Department of Haematology, Institute of Clinical Pathology and \\ Medical Research (ICPMR), Westmead Hospital, Westmead, \\ New South Wales, Australia
}

Semin Thromb Hemost 2015;41:1-6.

Welcome to the start of another year with Seminars in Thrombosis \& Hemostasis (STH). This is my 7th year as editor-in-chief, and my 10th year of editorial association with this journal, having originally served as a regional editor. First, I sincerely wish to thank all the contributors to STH over the past years, as well as the guest editors for these issues, and of course, the current and past senior and associate editors of the journal. There will be some changes to the editorial team over the forth coming 12 months, with an expansion of this team currently in plan. Also, Dr. Catherine Hayward has indicated she would like to step down from her role as senior editor. We sincerely thank her for her support in previous years and wish her continued success in her work. Last year represented a milestone for this journal, representing the 40th year of publication, a landmark that we celebrated with two special 40th anniversary celebratory issues. ${ }^{1,2}$

I will also take this opportunity to thank the journal production team at Thieme Medical Publishers for their high production standards and for facilitating both the print and online issues of the journal. In particular, I would like to thank Subhankar De, the production editor for STH for managing the production process of STH issues and articles. I also wish to thank Kelly Coffey, a journals coordinator for Thieme Medical Publishers, as well as other key people at Thieme, some of who prefer to remain unnamed, for the additional support provided over the recent years.

This is also a fitting time to once again reflect on our journal's impact factor, which was 3.693 for 2013. This represents a drop from our 2012 impact factor of 4.216 (-Fig. 1). I am hopeful that this pattern reflects some stabilization of the STH impact factor at around 4 over the coming years. It might be of some interest to note that the impact factor for most thrombosis and hemostasis focused journals fell in 2013 compared with 2012 values (-Fig. 2). The reason for this generalized fall in impact factor for thrombosis and hemostasis focused journals is unknown, although it could be at least in part due to continued development of additional publishing avenues from open access models. I have also previously highlighted, ${ }^{3,4}$ and would continue to assert, that the impact factor is not the only marker of journal "quality" that we should consider, given the existence of other biometric markers and the limitations of any individual marker (including the impact factor) as a "quality" indicator.

Nevertheless, for the potential interest of the readership and contributing authors, I have listed the highest 2013-cited, 2010/2011-published, contributions from this journal in - Table 1. ${ }^{5-62}$ These contributions identify those publications most contributing to the 2013 impact factor, and each was cited five or more times in 2013. The top

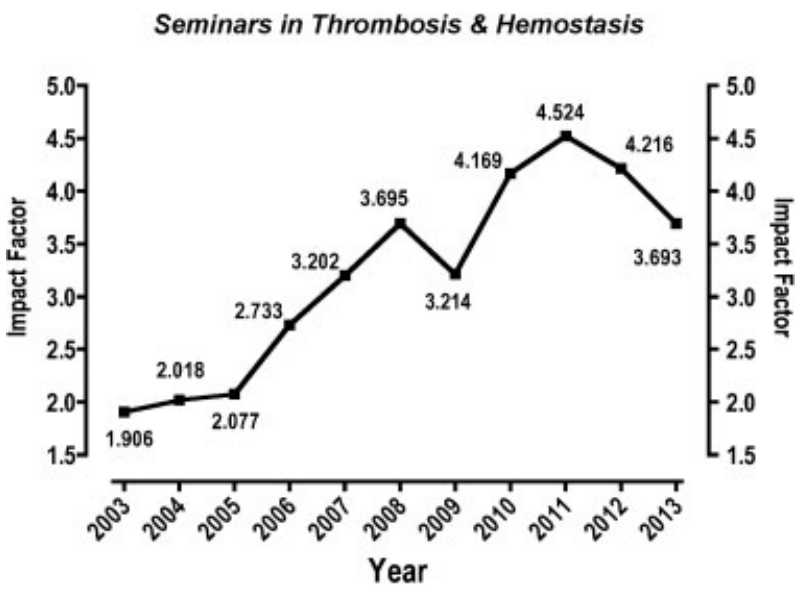

Fig. 1 The impact factor for Seminars in Thrombosis \& Hemostasis, from 2003 to 2013.
Address for correspondence Emmanuel J. Favaloro, PhD, FFSc (RCPA), Department of Haematology, Institute of Clinical Pathology and Medical Research (ICPMR), Westmead Hospital, Westmead, NSW 2145, Australia (e-mail: emmanuel. favaloro@health.nsw.gov.au).
Issue Theme Thrombosis and Hemostasis Issues in Critically III Patients; Guest Editor, Marcel Levi, MD, PhD.
Copyright $\odot 2015$ by Thieme Medical Publishers, Inc., 333 Seventh Avenue, New York, NY 10001, USA. Tel: +1(212) 584-4662.
DOI http://dx.doi.org/ 10.1055/s-0035-1544217. ISSN 0094-6176. 
Table 1 Most highly (2013) cited (2010/2011-published) contributions from Seminars in Thrombosis \& Hemostasis

1. Lippi G, Salvagno GL, Montagnana M, Lima-Oliveira G, Guidi GC, Favaloro EJ. Quality standards for sample collection in coagulation testing. Semin Thromb Hemost 2012;38(6):565-575

2. Harenberg J, Erdle S, Marx S, Krämer R. Determination of rivaroxaban in human plasma samples. Semin Thromb Hemost 2012;38(2):178-184

3. Allman-Farinelli MA. Obesity and venous thrombosis: a review. Semin Thromb Hemost 2011;37(8):903-907

4. Ichinose A. Hemorrhagic acquired factor XIII (13) deficiency and acquired hemorrhaphilia 13 revisited. Semin Thromb Hemost 2011;37(4):382-388

5. Kershaw G, Suresh S, Orellana D, Nguy YM. Laboratory identification of lupus anticoagulants. Semin Thromb Hemost 2012;38 (4):375-384

6. De Franceschi L, Cappellini MD, Olivieri O. Thrombosis and sickle cell disease. Semin Thromb Hemost 2011;37(3):226-236

7. Linden MD, Tran H, Woods R, Tonkin A. High platelet reactivity and antiplatelet therapy resistance. Semin Thromb Hemost 2012;38(2):200-212

8. Dentali F, Sironi AP, Ageno W, et al. Non-O blood type is the commonest genetic risk factor for VTE: results from a metaanalysis of the literature. Semin Thromb Hemost 2012;38(5):535-548

9. Willis R, Harris EN, Pierangeli SS. Pathogenesis of the antiphospholipid syndrome. Semin Thromb Hemost 2012;38(4):305-321

10. Ballmaier M, Germeshausen M. Congenital amegakaryocytic thrombocytopenia: clinical presentation, diagnosis, and treatment. Semin Thromb Hemost 2011;37(6):673-681

11. Adcock Funk DM, Lippi G, Favaloro EJ. Quality standards for sample processing, transportation, and storage in hemostasis testing. Semin Thromb Hemost 2012;38(6):576-585

12. Fava C, Montagnana M, Favaloro EJ, Guidi GC, Lippi G. Obstructive sleep apnea syndrome and cardiovascular diseases. Semin Thromb Hemost 2011;37(3):280-297

13. Harenberg J, Giese C, Marx S, Krämer R. Determination of dabigatran in human plasma samples. Semin Thromb Hemost 2012;38(1):16-22

14. Pengo V, Banzato A, Bison E, Bracco A, Denas G, Ruffatti A. What have we learned about antiphospholipid syndrome from patients and antiphospholipid carrier cohorts? Semin Thromb Hemost 2012;38(4):322-327

15. Preissner KT, Reuning U. Vitronectin in vascular context: facets of a multitalented matricellular protein. Semin Thromb Hemost 2011;37(4):408-424

16. Coppola A, Tagliaferri A, Di Capua M, Franchini M. Prophylaxis in children with hemophilia: evidence-based achievements, old and new challenges. Semin Thromb Hemost 2012;38(1):79-94

17. Lijfering WM, Flinterman LE, Vandenbroucke JP, Rosendaal FR, Cannegieter SC. Relationship between venous and arterial thrombosis: a review of the literature from a causal perspective. Semin Thromb Hemost 2011;37(8):885-896

18. Coppola A, Favaloro EJ, Tufano A, Di Minno MN, Cerbone AM, Franchini M. Acquired inhibitors of coagulation factors: part I-acquired hemophilia A. Semin Thromb Hemost 2012;38(5):433-446

19. Nurden AT, Pillois X, Fiore M, Heilig R, Nurden P. Glanzmann thrombasthenia-like syndromes associated with Macrothrombocytopenias and mutations in the genes encoding the $\alpha$ llb $\beta 3$ integrin. Semin Thromb Hemost 2011;37(6):698-706

20. Plebani M, Favaloro EJ, Lippi G. Patient safety and quality in laboratory and hemostasis testing: a renewed loop? Semin Thromb Hemost 2012;38(6):553-558

21. Lippi G, Cervellin G. Degradation of troponin I in serum or plasma: mechanisms, and analytical and clinical implications. Semin Thromb Hemost 2012;38(2):222-229

22. Favaloro EJ. Von Willebrand disease: local diagnosis and management of a globally distributed bleeding disorder. Semin Thromb Hemost 2011;37(5):440-455

23. Maas C, Oschatz C, Renné T. The plasma contact system 2.0. Semin Thromb Hemost 2011;37(4):375-381

24. Zeerleder S. C1-inhibitor: more than a serine protease inhibitor. Semin Thromb Hemost 2011;37(4):362-374

25. Zamagni E, Brioli A, Tacchetti P, Zannetti B, Pantani L, Cavo M. Multiple myeloma, venous thromboembolism, and treatmentrelated risk of thrombosis. Semin Thromb Hemost 2011;37(3):209-219

26. Aatonen M, Grönholm M, Siljander PR. Platelet-derived microvesicles: multitalented participants in intercellular communication. Semin Thromb Hemost 2012;38(1):102-113

27. Di Fabio F, Lykoudis P, Gordon PH. Thromboembolism in inflammatory bowel disease: an insidious association requiring a high degree of vigilance. Semin Thromb Hemost 2011;37(3):220-225

28. Tripodi A. To mix or not to mix in lupus anticoagulant testing? That is the question. Semin Thromb Hemost 2012;38(4):385-389

29. Favaloro EJ, Bonar R, Marsden K. Internal quality control and external quality assurance in testing for antiphospholipid antibodies: Part II-Lupus anticoagulant. Semin Thromb Hemost 2012;38(4):404-411

30. Blavignac J, Bunimov N, Rivard GE, Hayward CP. Quebec platelet disorder: update on pathogenesis, diagnosis, and treatment. Semin Thromb Hemost 2011;37(6):713-720

31. Hampshire DJ, Goodeve AC. The international society on thrombosis and haematosis von Willebrand disease database: an update. Semin Thromb Hemost 2011;37(5):470-479

32. Hayward CP, Moffat KA, Liu Y. Laboratory investigations for bleeding disorders. Semin Thromb Hemost 2012;38(7):742-752

33. Lippi G, Plebani M, Favaloro EJ. Interference in coagulation testing: focus on spurious hemolysis, icterus, and lipemia. Semin Thromb Hemost 2013;39(3):258-266

34. Lippi G, Favaloro EJ, Cervellin G. Prevention of venous thromboembolism: focus on mechanical prophylaxis. Semin Thromb Hemost 2011;37(3):237-251

35. Chapman K, Seldon M, Richards R. Thrombotic microangiopathies, thrombotic thrombocytopenic purpura, and ADAMTS-13. Semin Thromb Hemost 2012;38(1):47-54

36. Willis R, Harris EN, Pierangeli SS. Current international initiatives in antiphospholipid antibody testing. Semin Thromb Hemost 2012;38(4):360-374 
37. Targher G, Pichiri I, Lippi G. Vitamin D, thrombosis, and hemostasis: more than skin deep. Semin Thromb Hemost 2012;38 (1):114-124

38. Tufano A, Di Capua M, Coppola A, et al. The infectious burden in atherothrombosis. Semin Thromb Hemost 2012;38(5):515-523

39. Sørensen B, Larsen OH, Rea C), Tang M, Foley JH, Fenger-Eriksen C. Fibrinogen as a hemostatic agent. Semin Thromb Hemost 2012;38(3):268-273

40. Levi M, van der Poll T, Schultz M. Infection and inflammation as risk factors for thrombosis and atherosclerosis. Semin Thromb Hemost 2012;38(5):506-514

41. Kulkarni R, Soucie JM. Pediatric hemophilia: a review. Semin Thromb Hemost 2011;37(7):737-744

42. Tufano A, Coppola A, Cerbone AM, Ruosi C, Franchini M. Preventing postsurgical venous thromboembolism: pharmacological approaches. Semin Thromb Hemost 2011;37(3):252-266

43. van der Post JA, Lok CA, Boer K, Sturk A, Sargent IL, Nieuwland R. The functions of microparticles in pre-eclampsia. Semin Thromb Hemost 2011;37(2):146-152

44. Lockwood C], Huang S], Krikun G, et al. Decidual hemostasis, inflammation, and angiogenesis in pre-eclampsia. Semin Thromb Hemost 2011;37(2):158-164

45. Salmela B, Joutsi-Korhonen L, Armstrong E, Lassila R. Active online assessment of patients using new oral anticoagulants: bleeding risk, compliance, and coagulation analysis. Semin Thromb Hemost 2012;38(1):23-30

46. Federici AB, Bucciarelli P, Castaman G, et al. Management of inherited von Willebrand disease in Italy: results from the retrospective study on 1234 patients. Semin Thromb Hemost 2011;37(5):511-521

47. Franchini M, Lippi G, Favaloro EJ. Acquired inhibitors of coagulation factors: part II. Semin Thromb Hemost 2012;38(5):447-453

48. Prechel M, Walenga JM. Heparin-induced thrombocytopenia: an update. Semin Thromb Hemost 2012;38(5):483-496

49. Tufano A, Guida A, Di Minno MN, Prisco D, Cerbone AM, Di Minno G. Prevention of venous thromboembolism in medical patients with thrombocytopenia or with platelet dysfunction: a review of the literature. Semin Thromb Hemost 2011;37 (3):267-274

50. Stasi R. Immune thrombocytopenia: pathophysiologic and clinical update. Semin Thromb Hemost 2012;38(5):454-462

51. Favaloro EJ, Wheatland L, Jovanovich S, Roberts-Thomson P, Wong RC. Internal quality control and external quality assurance in testing for antiphospholipid antibodies: Part I-Anticardiolipin and anti- $\beta 2$-glycoprotein I antibodies. Semin Thromb Hemost 2012;38(4):390-403

52. de Groot PG, Urbanus RT. The future of antiphospholipid antibody testing. Semin Thromb Hemost 2012;38(4):412-420

53. Millikan PD, Balamohan SM, Raskind WH, Kacena MA. Inherited thrombocytopenia due to GATA-1 mutations. Semin Thromb Hemost 2011;37(6):682-689

54. Howard BM, Daley AT, Cohen MJ. Prohemostatic interventions in trauma: resuscitation-associated coagulopathy, acute traumatic coagulopathy, hemostatic resuscitation, and other hemostatic interventions. Semin Thromb Hemost 2012;38 (3):250-258

55. Montagnana M, Meschi T, Borghi L, Lippi G. Thrombosis and occlusion of vascular access in hemodialyzed patients. Semin Thromb Hemost 2011;37(8):946-954

56. Toriello HV. Thrombocytopenia-absent radius syndrome. Semin Thromb Hemost 2011;37(6):707-712

57. Di Paola J, Johnson J. Thrombocytopenias due to gray platelet syndrome or THC2 mutations. Semin Thromb Hemost 2011;37 (6):690-697

58. 58. Lippi G, Franchini M, Cervellin G. Diagnosis and management of ischemic heart disease. Semin Thromb Hemost 2013;39 (2):202-213

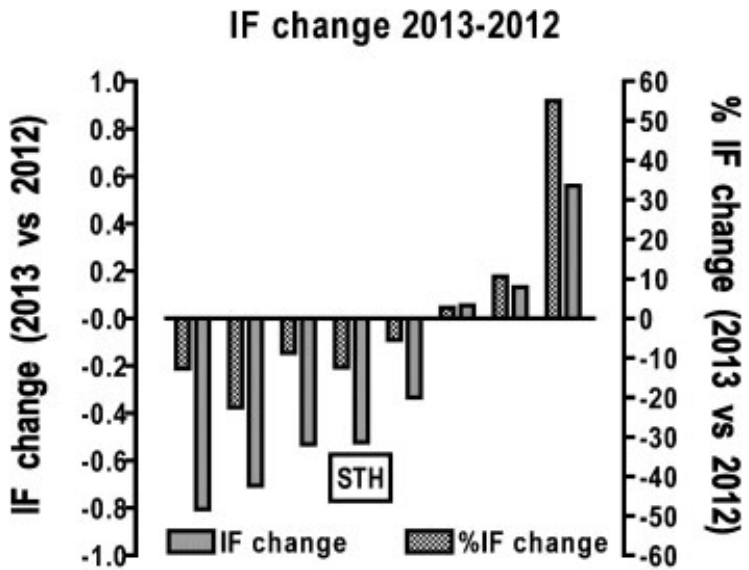

Fig. 2 The relative change in impact factor (IF) from 2012 to 2013 for eight thrombosis and hemostasis-focused journals. Data shown as IF change from 2012 to 2013 in absolute terms (left axis; gray bars) and as a percentage change (right axis; hatched bars). The data for Seminars in Thrombosis \& Hemostasis identified as STH.
Table 2 Current planned topics for future issues of Seminars in Thrombosis and Hemostasis

- Thrombosis and hemostasis issues in critically ill patients

- Anticoagulant therapy: present and future

- Current issues in hemophilia: recognizing clinical heterogeneity, replacement therapy, and outcome assessment

- Tissue factor in arterial and venous thrombosis. From pathophysiology to clinical implications

- Hemostatic dysfunction in liver diseases

- Hot topics VII (continuing series)

- Quality in thrombosis and hemostasis (continuing series) 
20 -listed articles ${ }^{5-24}$ were each actually cited 10 or more times in 2013. For those interested, the current listing can be compared with those of the most recently published top downloaded article listings from STH, the basis of the Eberhard Mammen "Most Popular" awards. ${ }^{63,64}$ Accordingly, I thank all the contributors, guest editors, and the editorial team for bringing us the content that makes STH.

Finally, a short note to confirm that we will continue to develop plans for the future content of this journal, and we are confident that we will be able to continue to bring you, the reader, the high-quality journal that you have come to expect. Currently confirmed topics for issues that we plan to publish over the next 12 or so months are listed in -Table $\mathbf{2}$. At the same time, we recognize the need to retain some flexibility in our plans, and to potentially add additional material of current interest and controversy as the need arises.

We look forward to another interesting year of reading in 2015 !

\section{References}

1 Favaloro EJ. A short history of thrombosis and hemostasis: part I (40th year celebratory issue). Semin Thromb Hemost 2014;40(5): 521-525

2 Favaloro EJ. A short history of thrombosis and hemostasis: part II (40th year celebratory issue). Semin Thromb Hemost 2014;40(8): 826-830

3 Favaloro EJ. The Journal Impact Factor: don't expect its demise any time soon. Clin Chem Lab Med 2009;47(11):1319-1324

4 Favaloro EJ. Measuring the quality of journals and journal articles: the impact factor tells but a portion of the story. Semin Thromb Hemost 2008;34(1):7-25

5 Lippi G, Salvagno GL, Montagnana M, Lima-Oliveira G, Guidi GC, Favaloro EJ. Quality standards for sample collection in coagulation testing. Semin Thromb Hemost 2012;38(6):565-575

6 Harenberg J, Erdle S, Marx S, Krämer R. Determination of rivaroxaban in human plasma samples. Semin Thromb Hemost 2012; 38(2):178-184

7 Allman-Farinelli MA. Obesity and venous thrombosis: a review. Semin Thromb Hemost 2011;37(8):903-907

8 Ichinose A. Hemorrhagic acquired factor XIII (13) deficiency and acquired hemorrhaphilia 13 revisited. Semin Thromb Hemost 2011;37(4):382-388

9 Kershaw G, Suresh S, Orellana D, Nguy YM. Laboratory identification of lupus anticoagulants. Semin Thromb Hemost 2012;38(4): 375-384

10 De Franceschi L, Cappellini MD, Olivieri O. Thrombosis and sickle cell disease. Semin Thromb Hemost 2011;37(3):226-236

11 Linden MD, Tran H, Woods R, Tonkin A. High platelet reactivity and antiplatelet therapy resistance. Semin Thromb Hemost 2012; 38(2):200-212

12 Dentali F, Sironi AP, Ageno W, et al. Non-O blood type is the commonest genetic risk factor for VTE: results from a meta-analysis of the literature. Semin Thromb Hemost 2012;38(5):535-548

13 Willis R, Harris EN, Pierangeli SS. Pathogenesis of the antiphospholipid syndrome. Semin Thromb Hemost 2012;38(4):305-321

14 Ballmaier M, Germeshausen M. Congenital amegakaryocytic thrombocytopenia: clinical presentation, diagnosis, and treatment. Semin Thromb Hemost 2011;37(6):673-681

15 Adcock Funk DM, Lippi G, Favaloro EJ. Quality standards for sample processing, transportation, and storage in hemostasis testing. Semin Thromb Hemost 2012;38(6):576-585
16 Fava C, Montagnana M, Favaloro EJ, Guidi GC, Lippi G. Obstructive sleep apnea syndrome and cardiovascular diseases. Semin Thromb Hemost 2011;37(3):280-297

17 Harenberg J, Giese C, Marx S, Krämer R. Determination of dabigatran in human plasma samples. Semin Thromb Hemost 2012; 38(1):16-22

18 Pengo V, Banzato A, Bison E, Bracco A, Denas G, Ruffatti A. What have we learned about antiphospholipid syndrome from patients and antiphospholipid carrier cohorts? Semin Thromb Hemost 2012;38(4):322-327

19 Preissner KT, Reuning U. Vitronectin in vascular context: facets of a multitalented matricellular protein. Semin Thromb Hemost 2011; 37(4):408-424

20 Coppola A, Tagliaferri A, Di Capua M, Franchini M. Prophylaxis in children with hemophilia: evidence-based achievements, old and new challenges. Semin Thromb Hemost 2012;38(1):79-94

21 Lijfering WM, Flinterman LE, Vandenbroucke JP, Rosendaal FR, Cannegieter SC. Relationship between venous and arterial thrombosis: a review of the literature from a causal perspective. Semin Thromb Hemost 2011;37(8):885-896

22 Coppola A, Favaloro EJ, Tufano A, Di Minno MN, Cerbone AM, Franchini M. Acquired inhibitors of coagulation factors: part Iacquired hemophilia A. Semin Thromb Hemost 2012;38(5): 433-446

23 Nurden AT, Pillois X, Fiore M, Heilig R, Nurden P. Glanzmann thrombasthenia-like syndromes associated with Macrothrombocytopenias and mutations in the genes encoding the $\alpha \operatorname{IIb} \beta 3$ integrin. Semin Thromb Hemost 2011;37(6):698-706

24 Plebani M, Favaloro EJ, Lippi G. Patient safety and quality in laboratory and hemostasis testing: a renewed loop? Semin Thromb Hemost 2012;38(6):553-558

25 Lippi G, Cervellin G. Degradation of troponin I in serum or plasma: mechanisms, and analytical and clinical implications. Semin Thromb Hemost 2012;38(2):222-229

26 Favaloro EJ. Von Willebrand disease: local diagnosis and management of a globally distributed bleeding disorder. Semin Thromb Hemost 2011;37(5):440-455

27 Maas C, Oschatz C, Renné T. The plasma contact system 2.0. Semin Thromb Hemost 2011;37(4):375-381

28 Zeerleder S. C1-inhibitor: more than a serine protease inhibitor. Semin Thromb Hemost 2011;37(4):362-374

29 Zamagni E, Brioli A, Tacchetti P, Zannetti B, Pantani L, Cavo M. Multiple myeloma, venous thromboembolism, and treatmentrelated risk of thrombosis. Semin Thromb Hemost 2011;37(3): 209-219

30 Aatonen M, Grönholm M, Siljander PR. Platelet-derived microvesicles: multitalented participants in intercellular communication. Semin Thromb Hemost 2012;38(1):102-113

31 Di Fabio F, Lykoudis P, Gordon PH. Thromboembolism in inflammatory bowel disease: an insidious association requiring a high degree of vigilance. Semin Thromb Hemost 2011;37(3):220-225

32 Tripodi A. To mix or not to mix in lupus anticoagulant testing? That is the question. Semin Thromb Hemost 2012;38(4): 385-389

33 Favaloro EJ, Bonar R, Marsden K. Internal quality control and external quality assurance in testing for antiphospholipid antibodies: Part II-Lupus anticoagulant. Semin Thromb Hemost 2012; 38(4):404-411

34 Blavignac J, Bunimov N, Rivard GE, Hayward CP. Quebec platelet disorder: update on pathogenesis, diagnosis, and treatment. Semin Thromb Hemost 2011;37(6):713-720

35 Hampshire DJ, Goodeve AC. The international society on thrombosis and haematosis von Willebrand disease database: an update. Semin Thromb Hemost 2011;37(5):470-479

36 Hayward CP, Moffat KA, Liu Y. Laboratory investigations for bleeding disorders. Semin Thromb Hemost 2012;38(7):742-752 
37 Lippi G, Plebani M, Favaloro EJ. Interference in coagulation testing: focus on spurious hemolysis, icterus, and lipemia. Semin Thromb Hemost 2013;39(3):258-266

38 Lippi G, Favaloro EJ, Cervellin G. Prevention of venous thromboembolism: focus on mechanical prophylaxis. Semin Thromb Hemost 2011;37(3):237-251

39 Chapman K, Seldon M, Richards R. Thrombotic microangiopathies, thrombotic thrombocytopenic purpura, and ADAMTS-13. Semin Thromb Hemost 2012;38(1):47-54

40 Willis R, Harris EN, Pierangeli SS. Current international initiatives in antiphospholipid antibody testing. Semin Thromb Hemost 2012;38(4):360-374

41 Targher G, Pichiri I, Lippi G. Vitamin D, thrombosis, and hemostasis: more than skin deep. Semin Thromb Hemost 2012;38(1):114-124

42 Tufano A, Di Capua M, Coppola A, et al. The infectious burden in atherothrombosis. Semin Thromb Hemost 2012;38(5):515-523

43 Sørensen B, Larsen OH, Rea CJ, Tang M, Foley JH, Fenger-Eriksen C. Fibrinogen as a hemostatic agent. Semin Thromb Hemost 2012; 38(3):268-273

44 Levi M, van der Poll T, Schultz M. Infection and inflammation as risk factors for thrombosis and atherosclerosis. Semin Thromb Hemost 2012;38(5):506-514

45 Kulkarni R, Soucie JM. Pediatric hemophilia: a review. Semin Thromb Hemost 2011;37(7):737-744

46 Tufano A, Coppola A, Cerbone AM, Ruosi C, Franchini M. Preventing postsurgical venous thromboembolism: pharmacological approaches. Semin Thromb Hemost 2011;37(3):252-266

47 van der Post JA, Lok CA, Boer K, Sturk A, Sargent IL, Nieuwland R. The functions of microparticles in pre-eclampsia. Semin Thromb Hemost 2011;37(2):146-152

48 Lockwood CJ, Huang SJ, Krikun G, et al. Decidual hemostasis, inflammation, and angiogenesis in pre-eclampsia. Semin Thromb Hemost 2011;37(2):158-164

49 Salmela B, Joutsi-Korhonen L, Armstrong E, Lassila R. Active online assessment of patients using new oral anticoagulants: bleeding risk, compliance, and coagulation analysis. Semin Thromb Hemost 2012;38(1):23-30

50 Federici $A B$, Bucciarelli P, Castaman G, et al. Management of inherited von Willebrand disease in Italy: results from the retrospective study on 1234 patients. Semin Thromb Hemost 2011; 37(5):511-521
51 Franchini M, Lippi G, Favaloro EJ. Acquired inhibitors of coagulation factors: part II. Semin Thromb Hemost 2012;38(5): 447-453

52 Prechel M, Walenga JM. Heparin-induced thrombocytopenia: an update. Semin Thromb Hemost 2012;38(5):483-496

53 Tufano A, Guida A, Di Minno MN, Prisco D, Cerbone AM, Di Minno G. Prevention of venous thromboembolism in medical patients with thrombocytopenia or with platelet dysfunction: a review of the literature. Semin Thromb Hemost 2011;37(3):267-274

54 Stasi R. Immune thrombocytopenia: pathophysiologic and clinical update. Semin Thromb Hemost 2012;38(5):454-462

55 Favaloro EJ, Wheatland L, Jovanovich S, Roberts-Thomson P, Wong RC. Internal quality control and external quality assurance in testing for antiphospholipid antibodies: Part I-Anticardiolipin and anti-ß2-glycoprotein I antibodies. Semin Thromb Hemost 2012;38(4):390-403

56 de Groot PG, Urbanus RT. The future of antiphospholipid antibody testing. Semin Thromb Hemost 2012;38(4):412-420

57 Millikan PD, Balamohan SM, Raskind WH, Kacena MA. Inherited thrombocytopenia due to GATA-1 mutations. Semin Thromb Hemost 2011;37(6):682-689

58 Howard BM, Daley AT, Cohen MJ. Prohemostatic interventions in trauma: resuscitation-associated coagulopathy, acute traumatic coagulopathy, hemostatic resuscitation, and other hemostatic interventions. Semin Thromb Hemost 2012;38(3):250-258

59 Montagnana M, Meschi T, Borghi L, Lippi G. Thrombosis and occlusion of vascular access in hemodialyzed patients. Semin Thromb Hemost 2011;37(8):946-954

60 Toriello HV. Thrombocytopenia-absent radius syndrome. Semin Thromb Hemost 2011;37(6):707-712

61 Di Paola J, Johnson J. Thrombocytopenias due to gray platelet syndrome or THC2 mutations. Semin Thromb Hemost 2011;37(6): 690-697

62 Lippi G, Franchini M, Cervellin G. Diagnosis and management of ischemic heart disease. Semin Thromb Hemost 2013;39(2): 202-213

63 Favaloro EJ. 2013 Eberhard F. Mammen award announcements. Semin Thromb Hemost 2013;39(6):567-574

64 Favaloro EJ. 2014 Eberhard F. Mammen Award announcements: Part I-Most popular articles. Semin Thromb Hemost 2014;40(4): 407-412 